János E. Szilágyi, Ph.D., Associate Professor

University of Miskolc

Faculty of Law

civdrede@uni-miskolc.hu

\title{
ACQUISITION OF THE OWNERSHIP OF AGRICULTURAL LANDS IN HUNGARY, TAKING THE EU'S AND OTHER COUNTRIES' LAW INTO CONSIDERATION
}

\begin{abstract}
The present article concentrates on the acquisition of ownership (and in some respects: use) of agricultural and forestry lands, especially as to the cross-border aspects. One of the hypotheses of the article is that the above mentioned issue is a topical question almost all around the world. Nevertheless, the article focuses on a European aspect of the cross-border acquisition, namely the new land law rules of the EU's Member States having joined the European Union in 2004 and 2007. In 2014 and 2015, the European Commission had assessed the land law of these Member States (i.e. Bulgaria, Hungary, Latvia, Lithuania, Slovakia) and initiated infringement procedures against these countries at the Court of Justice of the European Union. Besides the regulation of these new Member States of the EU, the present article deals with the legislation of other Member States as well as the provisions of non-EU states. The article gives substantial consideration to phenomena such as sovereignty, land-hunger or soil degradation which may exercise significant influence on the land law of a state.
\end{abstract}

Keywords: land law-farmland-agricultural land-acquisition of ownership.

The acquisition of the ownership of agricultural lands is a topical issue of the modern globalized world. ${ }^{1}$ In 2014, the European Commission started to assess the legislation of the Member States which became members of the European

${ }^{1}$ In connection with the topic, the activity of the European Council for Rural Law (according to its French abbreviation, hereinafter referred to as CEDR) is worth to be mentioned. The CEDR is "the only pan-European organization which represents lawyers and professionals interested in Rural Law, in a large sense, covering all aspects related to agricultural world. ... The CEDR has special consultative status with the United Nations [UN] Food and Agriculture Organization [FAO] and observatory status with the Council of Europe and regularly provides assistance and 
Union (EU) in 2004 or $2007^{2}$ (hereinafter referred to as New Member States) whether their provisions concerning the acquisition of the ownership of agricultural lands are compatible with the EU law, especially with its rules affecting the cross-border dimensions of acquisitions. Nevertheless, the present article's hypothesis is that the issue is relevant not merely for the New Member States of the EU, but also for other countries in and outside of the EU. For that very reason, beside the New Member States legislation, the present article equally deals with the factors which are able to affect the decision makers of the Member States in connection with the transfer of agricultural lands in their countries, and, furthermore, presents some interesting aspects of the legislation of the EU's Old Member States (states that joined the EU before 2004) and other non-EU countries. The article assesses the new land law ${ }^{3}$ of Hungary in detail as it is the Hungarian land law that criticised the most by the European Commission in comparison with the land law of other New Member States. Therefore the Hungarian land law reflects numerous specialities of the topical tendencies of land transfers.

\section{THE IMPORTANCE OF AGRICULTURAL LANDS IN THE $21^{\text {ST }}$ CENTURY}

Regarding factors which are able to affect the decision makers of the Member States in connection with transfer of agricultural lands in their countries, it is worth emphasizing three phenomena, namely (a) the criterion of independent and

advice to the institutions of the European Union [EU]'; See the webpage of the CEDR: http://www. cedr.org/

The CEDR handles the ownership and use of agricultural lands as a priority in its scientific activity; e.g. on 17.01.2014, the CEDR Management Board created three working groups to develop the three perspectives proposed by the representative of the EU Commission in Berlin. One of these groups was established in order "to work on the subject of land property and territory protection". Besides, numerous previous congresses of the CEDR dealt with certain aspects of the topic, and one of the three working commissions of the last CEDR Congress (Potsdam, 2015), i.e. Commission II, also focused on the acquisition of agricultural lands, especially on the 'the crossborder acquisitions of agricultural lands and the acquisitions of agricultural land by non-agricultural capital'. Hereinafter, on the one hand, the legislations of the EU and its Member States (MSs), moreover, on the other hand, the laws of some states outside of the EU are to be analysed primarily by the reports and the conclusion of the Commission II. See http://www.cedr.org/congresses/potsdam/potsdamcom2.php

${ }^{2}$ This paper was supported by the János Bolyai Research Scholarship of the Hungarian Academy of Sciences.

Croatia joined the European Union in 2013. According to its Accession Treaty, Croatia also has a transitional period during which it may apply a temporary derogation to the acquisition of ownership of agricultural lands. The duration of this transitional period is seven years which can be extended with additional three years.

${ }^{3}$ In the present article, land law means the legal provisions of a state which determine the ownership and the use of agricultural and forestry lands. 
sovereign states, (b) land-hunger along with its reasons and consequences, and (c) finally, the effect of soil degradation.

\subsection{Territory (lands) as the essential criterion of independent and sovereign states}

The territory of states has always been a significant issue in human history. Namely, if a state is not able to rule and decide over its territory, this state cannot be regarded as an independent and sovereign state. This statement is reflected in the jurisprudence; for example, according to the definition of sovereign states determined by international public law, the main criteria of a sovereign state are its defined territory, permanent population, government and capacity to enter into relations with the other states ${ }^{4}$ (others mention only three criteria: territory, population and political authority ${ }^{5}$ ). In other words, the relationship between these four criteria is elementary for the states, and without one of these components we cannot speak of a sovereign state. As regards the territory, it should be noted that, on the one hand, agricultural lands are elementary parts of the territory of a state, and, on the other hand, the ownership-system over the territory of a state (including agricultural and forestry lands) might affect the political authority and sovereignty of a state; namely, beyond a certain extent, ownership is not merely a private law issue, but has an influence on the political sphere as well. Therefore, it shall not be indifferent to a state who owns, uses and possesses its agricultural and forestry lands and in what a way. ${ }^{6}$ Finally, it is worth noticing that the modern political and scientific disputes on this topic are often referred to as the phenomenon of food security. ${ }^{7}$ The concept of food security is highly represented by the Food and Agriculture Organization of the United Nations, especially as the potential solution against the harmful effects of the globalization.

${ }^{4}$ Antônio Augusto CançadoTrindade, International law for humankind, Martinus Nijhoff Publishers, Leiden-Boston, 2010, 167; Malcolm Shaw, International law, Cambridge University Press, Cambridge, 2003, 178.

${ }^{5}$ See Georg Jellinek's theory in Péter Kovács, Nemzetközi közjog, Osiris Kiadó, Budapest, 2006, 165.

${ }^{6}$ Cf. Luka Baturan, Economic Analysis of the Ban on Foreigners to Acquiring Property Rights on Agricultural Land in Serbia. Economic of Agriculture, 3/2013, 479-491; Luka Baturan, The ban on Foreigners Acquiring Property Rights on Agricultural and Forest Land in Serbia and Other Regional Countries. Zbornik radova Pravnog fakulteta uNovom Sadu, 2/2013, 515-531; Csilla Csák, Zoltán Nagy, Regulation of obligation of use regarding the agricultural land in Hungary. Zbornik radova Pravnog fakulteta, Novi Sad, 2/2011, 541-550.

${ }^{7}$ Christian Häberli, FionaSmith, Food security and agri-foreign direct investment in weak states - Finding the governance gap to avoid 'land grab', Modern Law Review, 2/2014, 189-222; Olivier de Schutter, The specter of productivism and food democracy, Wisconsin Law Review, 2/2014, 199-233. 


\subsection{Land-hunger}

In the $21^{\text {st }}$ century, because of the growing population pressure and the increasing human demand deriving from this change of population, there is a growing hunger for agricultural lands. ${ }^{8}$ Due to the significant differences among the land prices of the various regions in the world, land-hunger appears in several forms all around the world. For instance, in a number of countries, mostly in the developing world and in Central Europe, the so-called land-grabbing should be mentioned. Land-grabbing means the acquisition or long-term lease of large portions of agricultural land (above 1,000 ha) in the above mentioned countries. ${ }^{9}$

\subsection{Soil degradation}

Besides the growing land-hunger, there is another important change affecting the use of agricultural lands almost all around the world. Namely, as a consequence of certain human-induced processes, humankind also has to take the growing soil degradation (soil erosion) into account. It is estimated that up to 40 per-cent of the world's agricultural land is seriously degraded. Soil degradation is also able to stimulate the above mentioned land-hunger in a region with a better quality of soil than in a region strongly influenced by soil erosion.

\section{OUTSIDE OF THE EUROPEAN UNION}

Non-EU countries dealt in numerous ways with the acquisition of agricultural lands and its cross-border aspects. Below, merely some of these countries' legislation will be mentioned regarding the national reports presented in a Congress of the European Council for Rural Law (CEDR) in 2015.

Brazilian law distinguishes between the direct and indirect acquisitions of agricultural lands in Brazil. Indirect acquisition - i.e. when foreign natural and legal persons participating in a Brazilian company acquire agricultural land (i.e. they have the majority of the capital stock of that Brazilian company) - is not prohibited by the Brazilian law. ${ }^{10}$ As regards the direct acquisition of agricultural lands in Brazil, there are two options: (a) non-resident foreigners and foreign companies not authorized to operate in Brazil are not enabled to acquire agricultural

${ }^{8}$ Olivier de Schutter, The green rush: The global race for farmland and the rights of land users, Harvard International Law Journal, 2/2011, 503-559; Elizabeth Gorman, When the poor have nothing left to eat: the United States' obligation to regulate American investment in the African land grab, Ohio State Law Journal, 1/2014, 199-235.

${ }^{9}$ UN General Assembly: A/HRC/13/33/Add.2, 5-6.

${ }^{10}$ Lutero de Paiva Pereira, National report - Brazil, 3. (hereinafter referred to as Brazilian report), the report is to be found at http://www.cedr.org/congresses/potsdam/potsdamcom2.php 
lands in Brazil; (b) besides, a foreign individual living in Brazil and a foreign company authorized to operate in Brazil are enabled to acquire agricultural lands in Brazil. ${ }^{11}$

In Argentina, "law $N^{\circ} 26737 / 2011$, commonly named the foreign ownership law, limits to foreigners (whether natural or legal persons) the acquisition, transference and assignment of possessory rights on rural land in the country... [T] he law limited to a maximum percentage the amount of rural land to the ownership or possession by [foreign natural persons]"12. Argentinean law also applies a prior authorization system in connection with lands. ${ }^{13}$

The US report presents that "[t]he United States enjoys large expanses of productive agricultural land and even more timber and forest land. Ownership of these lands is attractive for investors, as well as for agricultural producers. National concerns about ownership of agricultural land by foreign investors have resulted in federal disclosure requirements. In addition, states have authority to regulate land within their borders, using their general "police power." Some states have restricted the ownership of farmland by aliens, residents of other states, or business entities, particularly corporations." 14 At federal level, it is worth noticing the so-called Agricultural Foreign Investment Disclosure Act (AFIDA), which "requires foreign investors to report their holdings. The law requires any 'foreign person who acquires or transfers any interest ... in agricultural land' to report that transaction to the US Secretary of Agriculture within 90 days." 15 The US national report draws the attention to the definition of a foreign person as well: 'AFIDA defines 'person' broadly to include both individuals and legal entities (e.g., corporations, associations, and others). 'Foreign person' includes any individual who is not a citizen or permanent resident of the United States and any foreign government. It also includes a legal entity created under the laws of a foreign government or with its principal place of business outside the United States. In addition, it includes an entity created under the laws of a US state, but in which a 'significant interest' (defined by regulation) is held by foreign persons (individuals, entities, or governments)."16 The AFIDA can provide a proper model for all the countries which really and effectively intend to trace the ownership system of their agricultural lands and territories.

${ }^{11}$ Brazilian report, 3.

${ }^{12}$ Maria Adriana Victoria, Nancy Malanos, National report - Argentina, 3. (hereinafter referred to as Argentinean report), the report is to be found at http://www.cedr.org/congresses/ potsdam/potsdamcom2.php

${ }^{13}$ Argentinean report, 3.

${ }^{14}$ Margaret Rosso Grossman, National report - USA, 15, (hereinafter referred to as US-report), the report is to be found at http://www.cedr.org/congresses/potsdam/potsdamcom2.php

${ }^{15}$ US-report, 15-16.

${ }^{16}$ US-report, 16. 
Norway is not a member of the European Union but it is a member of the European Economic Area. Therefore the four freedoms (i.e. of capital, persons, goods and services) of the EU law are also compulsory provisions for the country. Taking these EU law requirements into consideration, Norway adopted an EU conform - but restrictive - land law ${ }^{17}$. Nevertheless, a recent proposal of the Norwegian decision makers is quite extraordinary regarding the land law tendencies of other European countries; namely, according to the Norwegian plan, the decision makers intend to liberalize the land market of Norway. ${ }^{18}$

The status of Switzerland may be regarded similarly to that of Norway. Although Switzerland is a member of the European Free Trade Area as well, it is not part of the European Economic Area. The Swiss land law in force was adopted even taking the EU law into consideration. ${ }^{19}$ The Swiss land law considerably differs per canton. ${ }^{20}$ The Swiss report presents that the Swiss law intends to avoid the increase of agricultural land prices because of the non-agricultural buyers of lands. The Swiss law (BGBB) determines the persons who are enabled to acquire agricultural lands in the agricultural zone, as a result of which the Swiss land law significantly stabilizes the market of agricultural lands. ${ }^{21}$ Namely, only an agricultural producer who independently farms is enabled to buy agricultural lands in the agricultural zone. ${ }^{22}$ Numerous types of state control, a strict order of possible buyers/successors, distinction between agricultural land and holding, as well as special rules concerning the ownership, use and succession of agricultural lands and holdings may serve to maintain agricultural lands for agricultural purposes and in the hands of locals willing and being able to farm them.

\section{EU LAW AND EU MEMBER STATES}

The European Union is not a federal state, but a particular international phenomenon which is based on the regime of the international treaties (e.g. the TFEU) signed by sovereign and independent states (i.e. by the Member States of the EU). In the EU, the regularization of the agricultural lands' market is the competence of the Member States, however, the Member States (MSs) shall adopt provisions in compliance with the EU law.

${ }^{17}$ See Act of 2003 relating to concession in the acquisition of real property (Concession Act).

${ }^{18}$ Ingrid AAsen, Erlend Daling, National report - Norway, 5, (hereinafter referred to as Norwegian report), the report is to be found at http://www.cedr.org/congresses/potsdam/potsdamcom2.php

${ }^{19}$ Philippe Haymoz, Bäuerliches Bodenrecht - Unterlagen für eine Übersicht und Einführung zum BGBB, 2011.

${ }^{20}$ Jörg Amsler, National report - Switzerland, 3. (hereinafter referred to as Swiss report), the report is to be found at http://www.cedr.org/congresses/potsdam/potsdamcom2.php

${ }^{21}$ Swiss report, 3.

22 Swiss report, 5. 


\subsection{EU law}

First of all, it is worth noticing that the EU law does not prohibit MSs measures restricting the acquisition of agricultural land by entities from outside of the EU or the European Economic Area (EEA). Nonetheless, inside the EU and the EEA, the EU law, on the one hand, requires the implementation of the four EU freedoms of the internal market (in connection with the acquisition of agricultural lands, the free movement of persons and capital are applicable) and, on the other hand, it prohibits the discrimination on the basis of nationality. ${ }^{23}$

The concerned rules of the Treaty on the Functioning of the European Union (TFEU) are especially the free movement of persons and capital ${ }^{24}$ (Articles 49 and 63 of the TFEU; hereinafter referred to as 'negative integration rules') and an objective ("to ensure a fair standard of living for the agricultural community") of the Common Agricultural Policy (CAP) of the EU (i.e. Article 39 (1) point b) of the TFEU; hereinafter referred to as 'positive integration rules'). ${ }^{25}$ According to Agoston Korom, ${ }^{26}$ beside the anti-discrimination rules, the EU law determines the competence of its MSs to adopt their national land law in the intersection of negative and positive integration rules. The mentioned TFEU rules contain rather general provisions, therefore, the Court of Justice of the EU (CJEU) has an important role to interpret them and to help assess the national land laws of the MSs. As regards the negative integration rules, according to the practice of the CJEU, national law can ensure full compliance with the EU law (a) if the public interest is pursued by the national law (i.e. objectives in the public interest) and (b) if the measure of the national law cannot be exchanged for less restrictive measures (i.e. the principle of proportionality). As regards the objectives in the public interest, the $\mathrm{CJEU}^{27}$ regards the objectives of national agricultural land policy such as (a1) to preserve a permanent agricultural community, (a2) that the land should belong

${ }^{23}$ Csilla Csák, Bianka Kocsis, Aniko Raisz, National report - Hungary, 10-11. (hereinafter referred to as Hungarian report II), the report is to be found at http://www.cedr.org/congresses/ potsdam/potsdamcom2.php; see furthermore János Ede Szilágyi, The Accession Treaties of the New Member States and the national legislations, particularly the Hungarian law, concerning the ownership of agricultural land, Journal of Agricultural and Environmental Law (JAEL), 9/2010, 52-55.

${ }^{24}$ It is worth noticing that, according to Annex I of Council directive 88/361/EEC, investments in real estate on national territory by non-residents are part of the capital movements in the EU.

${ }^{25}$ About distinction between the negative and positive integration models and rules of the EU, see Ágoston Korom, Az új földtörvény az uniós jog tükrében - Jogegyenlőség vagy de facto más elbírálás, in: Az új magyar földforgalmi szabályozás az uniós jogban (ed.: Ágoston Korom), Nemzeti Közszolgálati Egyetem, Budapest, 2013, 14.

${ }^{26}$ Korom (2013), 14.

${ }^{27}$ See from the jurisdiction of the CJEU Case 182/83, judgment of the Court of 6 November 1984 (Fearon case), point 3; Case C-302/97, judgment of the Court of 1 June 1999 (Konle case), point 40; Case C-515/99, Judgment of the Court of 5 March 2002 (Reisch case), point 34; Case C-300/01, Judgment of the Court of 15 May 2003 (Salzmann case), point 44; Case C-452/01, Judgment of the Court of 23 September 2003 (Ospelt case), points 38-39; and Case C-370/05 (Festersen case), 
to persons wishing (and being capable) to farm it, (a3) the possibility to counteract speculative land acquisition, (a4) etc. to be conform to the TFEU and to pursue an objective in the public interest. The restrictive measures accepted by the jurisdiction of the CJEU are (b1) the procedure of prior authorisation for the acquisition of agricultural land, ${ }^{28}$ (b2) the system of prior declaration, ${ }^{29}$ (b3) the provision for a higher tax on the resale of land occurring shortly after acquisition, ${ }^{30}$ (b4) the requirement of a substantial minimum duration for leases of agricultural land, ${ }^{31}$ (b5) etc.

\subsection{Member States law}

A significant percentage of the MSs apply some kind of a regulation and restrictions concerning the transaction of agricultural and forestry lands and/or agricultural holdings ${ }^{32}$. The decisive method of these legislations can differ from ius strictum (strict and rigorous rules) to ius equitum (permissive and allowing rules). They can determine provisions concerning agricultural producers; for example (a) vocational requirement (e.g. in Austria, Slovakia) or (b) restrictions against a person who does not pursue agricultural and/or forestry activity (e.g. the Netherlands, Germany). The transactions affected by the legislation might vary from the ownership through the use (e.g. lease) to the inheritance of agricultural lands/holdings; for example, (a) the determination of the maximum amount of agricultural lands owned or possessed by a person (e.g. Poland, Hungary), (b) pre-emptive rights (e.g. Italy, Portugal, the Netherlands), (c) a prior authorization procedure for the acquisition of agricultural lands (e.g. Austria, Hungary), (d) the requirement of a maximum duration for leases of agricultural land (e.g. Belgium, Greece, Italy, Germany), (e) etc.

Inside the EU, the difference between the land markets of the MSs is remarkable $^{33}$. This difference is especially significant between the land prices of the new MSs (i.e. MSs since 2004) and the Old MSs (namely MSs before 2004).

Nevertheless, the price is not the only reason for MSs to regulate their land markets. Below, the reasons of the Old MSs are detailed as well.

points 27-28., 33. The cases may be downloaded from the website: http://eur-lex.europa.eu/homepage.html

${ }^{28}$ See Case C-213/04 Ewald Burtscher v Josef Stauderer [2005] ECR I-10309, paragraph 57; and Case C-452/01, paragraphs 41-45.

${ }^{29}$ See Case C-213/04, paragraphs 44, 52-54, 59-62.

${ }^{30}$ See Case C-370/05, paragraph 39.

${ }^{31}$ See Case C-370/05, paragraph 39.

${ }^{32}$ Agricultural holding means the basic organizational unit of production equipment and other means of agricultural production (land, agricultural equipment, other assets) in connection with the ownership-use-succession relations in national laws where this category exists.

${ }^{33}$ See the data of the Eurostat: http://ec.europa.eu/eurostat/web/agriculture/data/database (subsection: 'apri'). 


\subsubsection{New MSs and especially the new Hungarian land law}

Below, the legislation (and the respective infringement procedures) of new MSs and, as an example, the main provisions of the new Hungarian land law are presented.

As regards the legislation of new MSs in a general sense, with regard to their low land prices and on the basis of the Accession Treaties of 2003, 2005 and 2012, (since 2004) the Czech Republic, Estonia, Latvia, Lithuania, Hungary, Poland, Slovakia, (since 2007) Romania, Bulgaria and (since 2013) Croatia (new MSs) were each granted a transitional period for maintaining existing legislation restricting the acquisition of the ownership ${ }^{34}$ of agricultural lands and forests, by derogation from the freedom of capital movements.

After the transitional period had expired, numerous new MSs adopted new land laws including restrictive measures. Typically, the legislation of Old MSs provided a role model for the new MSs (the French and Austrian models were quite popular among them). In 2015, the EU Commission introduced infringement procedures against some of the new MSs; namely Bulgaria, Hungary, Latvia, Lithuania, Slovakia. In the opinion of the EU Commission, some provisions of these MSs are considered as the violation of the free movement of capital and the freedom of establishment, and therefore, this situation discourages cross-border investment in the land market of the new MSs. "The main concern in Bulgaria and Slovakia is that buyers must be long-term residents in the country, which discriminates against other EU nationals. Hungary has a very restrictive system which imposes a complete ban on the acquisition of land by legal entities and an obligation on the buyer to farm the land himself. In addition, as in Latvia and Lithuania, buyers must qualify as farmers. While the Commission agrees that national authorities should be able to properly regulate farm land markets to maintain such land in agricultural use and promote local development, it found a number of these measures excessively restrictive and discriminatory in terms of attracting investment in rural development." 35

However, it is worth emphasizing that, till 2014, the preliminary ruling has been typical, the infringement remains exceptional in connection with the acquisition of agricultural lands. ${ }^{36}$

${ }^{34}$ Namely, there are generally no restrictions on the lease of agricultural lands by foreigners.

${ }^{35}$ European Commission, Press release on „Financial services: Commission requests Bulgaria, Hungary, Latvia, Lithuania and Slovakia to comply with EU rules on the acquisition of agricultural land", Brussels, 26 May 2016, IP/16/1827.

${ }^{36}$ E.g. CJEU Case 305/87, Judgment of the Court of 30 May 1989. About the infringement (Nr. 2007/4766) procedure of EU Commission against Voralberg act (Austria), see furthermore Roland Norer, General report Commission III - Scientific and practical development of rural law in the EU, in states and regions and in the WTO, in: L'agriculture et les exigencies du développement durable (ed.: Paul Richli), L'Harmattan, Paris, 2013, 375-376. 
As for the Hungarian land law in detail,${ }^{37}$ the new land law regime of Hungary was adopted in 2013. It should be noted that the new land law regime includes numerous acts and decrees and even some provisions of the new Hungarian constitution $^{38}$ (called Fundamental Law). Nevertheless, the essential element of this new land law regime is Act CXXII of 2013 on transactions in agricultural and forestry lands (hereinafter referred to as TAL). The main provisions of the new land

${ }^{37}$ In connection with the Hungarian land law, see especially the following pieces of excellent research Krisztina Bányai, Theoretical and practical issues of restraints of land acquisition in Hungary, Journal of Agricultural and Environmental Law, 20/2016, 5-15; Csilla Csák, Bianka Enikő Kocsis, Anikó Raisz, Vectors and indicators of agricultural policy and law from the point of view of the agricultural land structure, Journal of Agricultural and Environmental Law, 19/2015, 32-55; Csilla Csák, Die ungarische Regulierung der Eigentums- und Nutzungsverhältnisse des Ackerbodens nach dem Beitritt zur Europäischen Union, Journal of Agricultural and Environmental Law, 9/2010, 20-31; Csilla Csák, Zoltán Nagy, Regulation of Obligation of Use Regarding the Agricultural Land in Hungary, Zbornik radova Pravnog fakulteta u Novom Sadu, 2/2011, 541-549; Márk Gyovai, Eszter Kiss-Kondás, Regulations of auction of agricultural and forestry lands particularly regarding to Judicial Enforcement Procedure, Journal of Agricultural and Environmental Law, 20/2016, 50-63; Klaudia Holló, Zsófia Hornyák, Zoltán Nagy, Die Entwicklung des Agrarrechts in Ungarn zwischen 2013 und 2015, Journal of Agricultural and Environmental Law, 19/2015, 56-72; Zsófia Hornyák, Die Voraussetzungen und die Beschränkungen des landwirtschaftlichen Grunderwerbes in rechtsvergleichender Analyse, CEDR Journal of Rural Law, 1/2015, 88-97; Bianka Enikö Kocsis, The new Hungarian land transfer regulation from the aspect of examination of the European Union, Journal of Agricultural and Environmental Law, 16/2014, 95-110; István Olajos, Die Entscheidung des Verfassungsgerichts über die Rolle, die Entscheidungen und die Begründetheit der Gründen der Stellungnahmen der örtlichen Grundverkehrskommissionen, Agrar- und Umweltrecht, in press; Mihály Kurucz, Critical analyses of arable land regulation in Hungary, Journal of Agricultural and Environmental Law, 3/2007, 17-47; Ildikó Gyurán, István Olajos, The Hungarian National Report on Rural Use and Protection of Land in the Countryside, Journal of Agricultural and Environmental Law, 12/2012, 85-87, 92-94; István Olajos, Szabolcs Szilágyi, The most important changes in the field of agricultural law in Hungary between 2011 and 2013, Journal of Agricultural and Environmental Law, 15/2013, 94-97; István Olajos, Anikó Raisz, The Hungarian National Report on Scientific and Practical Development of Rural Law in the EU, in States and Regions and in the WTO, Journal of Agricultural and Environmental Law, 8/2010, 44-45; Endre Tanka, Why has the general land consolidation no chance in Hungary?, Journal of Agricultural and Environmental Law, 1/2006, 23-28.

${ }^{38}$ On the high-level assessment of the constitutional aspects of Hungarian land law, see Bobvos Pál, Erika Farkas Csamangó, Péter Hegyes, Péter Jani, A mező- és erdőgazdasági földek alapjogi védelme, in: Számadás az Alaptörvényröl (ed.: Elemér Balogh), Magyar Közlöny Lap- és Könyvkiadó, Budapest, 2016, 31-40; Csilla Csák, Nóra Jakab, The Hungarian National Report on Agriculture and the requirements of a sustainable development, Journal of Agricultural and Environmental Law, 12/2012, 50-51; Gergely Horváth, The renewed constitutional level of environmental law in Hungary, Acta Juridica Hungarica, 4/2015, 302-316; László Fodor, A víz az Alaptörvény környezeti értékrendjében, Publicationes Universitatis Miskolcinensis Sectio Juridica et Politica, 31/2013, 335-336, 339-342; Anikó Raisz, A Constitution's Environment, Environment in the Constitution, Est Europa, numéro spécial /2012, 50-70; András Téglási, How is property ownership guaranteed constitutionally in the field of agriculture?, Journal of Agricultural and Environmental Law, 7/2009, 20-21. 
law regime, and especially of the TAL, are the following: (a) The scope of the land law regime encompasses almost all the transactions of the ownership and the use of agricultural and forestry lands except for the succession by law. ${ }^{39}$ (b) There is a distinction between foreigners; namely, while non-EU foreigners shall not acquire the ownership and use of agricultural lands, the citizens of EU MSs, citizens of the European Economic Area and nationals of other States enjoying similar treatment under an international agreement can acquire the ownership of agricultural lands under the same conditions as Hungarians..$^{40}$ (c) Neither Hungarian nor foreign legal entities shall acquire the ownership of agricultural lands; there are some exceptions (i.e. the Hungarian state, municipal governments, listed churches, mortgage loan companies).$^{41}$ (d) Only for an agricultural purpose can somebody acquire the ownership or usage of agricultural lands ${ }^{42}$ with an obligation on the buyer or user to farm the land himself, ${ }^{43}$ and to possess a proper degree in agricultural or forestry activities, or the proper agricultural or forestry practice in Hungary (at least 3 years).$^{44}$ (e) The size of lands being subject of transfer is limited. The one of them is the so-called land acquisition limit of farmers. According to this, the size of land that may be acquired by a farmer may not exceed 300 hectares, including the size of land he/she may already own or use under usufructuary right (the limit of no-farmers is merely one hectare). ${ }^{45}$ Another limit is the so-called land possession limit of farmers and agricultural producer organizations. By virtue of this limit, the size of land that may be held in possession by a farmer or an agricultural producer organizations may not exceed 1,200 hectares (exceptionally: $1800 \mathrm{ha}$ ), including the size of land already held in possession. ${ }^{46}$ (f) Contracts for the transfer of ownership and land use rights shall be approved by the agricultural administration body (this is a condition of validity). ${ }^{47}(\mathrm{~g})$ During the procedure of the agricultural administration body local agricultural communities ${ }^{48}$ have the right to prevent the acquisition of the ownership of lands of a speculative nature via their opinion for the refusal of approval of the contracts. ${ }^{49}$ (h1) In the sale of

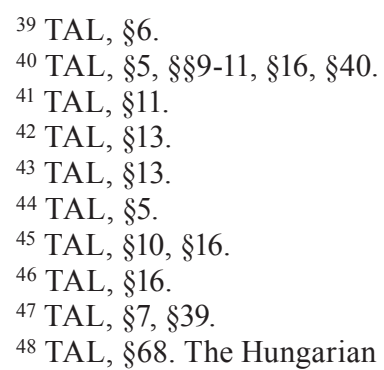
concerning local agricultural communities in its numerous procedures; see István Olajos, Az Alkotmánybíróság döntése a helyi földbizottságok szerepéről, döntéseiről, és az állásfoglalásuk indokainak megalapozottságáról, Jogesetek Magyarázata, 3/2015, 17-32.

49 TAL, $\S 23-24$. 
land the preemption right, ${ }^{50}(\mathrm{~h} 2)$ in the leasing of land the right of first refusal ${ }^{51}$ shall accrue in a strict statutory order. In preemption right statutory order, the Hungarian state has a preemption right at the first place. Both in the preemption right statutory order and in the right of first refusal statutory order, the local residency and agricultural production at a high level (e.g. AOC-food and bio-food production or animal keeping) mean a significant advantage in the orders. (i) There are strict rules to prevent the infringement of the restrictions, which means e.g. monitoring by the authorities, fines, and regulatory use of the land if the new owner does not fulfil his/her previously accepted obligations. ${ }^{52}$

\subsubsection{Old MSs}

The new tendencies detailed below present that the acquisition of ownership of agricultural lands is a topical issue in the Old MSs of the EU as well.

In Germany, ${ }^{53}$ a re-assessment of the land policy is underway. It is partly because of recent trends; i.e. the increasing prices of agricultural lands in numerous regions of Germany. According to the German report, even non-agricultural investors appeared in the market of agricultural lands. This situation raised concerns, because agricultural producers worry about the loss of their development potential. Since 2008 (after the financial crisis), wealthy persons and corporations have acquired agricultural lands all around Germany, and especially in the Eastern provinces of Germany. Therefore, in numerous regions of Germany, land prices have increased to a price-level at which agricultural holdings cannot put up the money from their profit to acquire further agricultural lands. ${ }^{54}$

In Austria, land law ${ }^{55}$ distinguishes between the acquisitions of green real estate (i.e. agricultural lands), grey real estate (i.e. real estate for building) and real estate acquisitions by foreigners. The regulation of these acquisitions is in the competence of the constituent states. In the Western constituent states of Austria (e.g. Tirol, Kitzbühel), the acquisition of agricultural lands by foreigners for non-

50 TAL, $\S \S 18-20$.

${ }^{51}$ TAL, $\S \S 45-48$.

52 TAL, $\$ \S 60-67$.

53 About the German land law, see Christian Grimm, Agrarrecht, Verlag C.H. Beck, München, 2010, 17-97.

${ }^{54}$ However, the acquisition of lands for nature conservation purposes by private foundations and financial funds is an utterly interesting aspect of the German land market; Udo Hemmerling, Deutscher Bauernverband - Position zum Bodenmarkt, Boppard, 14.10.2014, 1.; the report is to be found at http://www.cedr.org/congresses/potsdam/potsdamcom2.php

${ }^{55}$ Gottfried Holzer, Grundverkehrsrecht, in: Handbuch des Agrarrechts (ed.: Roland Norer), Verlag Österreich, Wien, 2012, 673-701; about lease, see Christian Stollmayer, Landpachtrecht, in: Handbuch des Agrarrechts (ed.: Roland Norer), Verlag Österreich, Wien, 2012, 703-716; see furthermore Anton Reinl, Family farms in Austria, in: Agricultura Familiar (ed.: Leticia Bourges, Esther Muniz Espada), Ministerio de Agricultura, Madrid, 2014, 51-53. 
-agricultural purposes is an evergreen topic of the agricultural policy. The political dispute about this topic is known as 'buying up the agricultural lands' (Ausverkauf von Grund und Boden). The land laws of the constituent states (e.g. the provisions concerning the obligatory land use by the person acquiring the affected land) had to be amended several times, in order to be compatible with the EU law. Their present versions nevertheless include many restrictions concerning the acquisition of agricultural lands and take the so-called land-transfer committee into the prior authorization procedure for the acquisition of agricultural land..$^{56}$

In connection with the British law ${ }^{57}$, the British report notes that "[c]urrently there are no restrictions on ownership of land by foreign nationals or companies within the UK in respect of most agricultural real estate. Despite this there are political moves within Scotland to limit ownership by non-EU nationals. The political mood in Scotland is that there are too many non-domiciled or otherwise distant landowners owning large rural estates, and that the sustainable development of the countryside is adversely effected." 58 The report highlights that "[t]here are no nationally collated figures available for foreign investment in UK agricultural land... Whilst there may be no wholly reliable statistical evidence for cross-border acquisitions, there is plenty of anecdotal evidence from real estate agents and others. This suggests that the stable nature of the English and Welsh land market and fiscal incentives have encouraged both foreign buyers and other investors within the UK". ${ }^{59}$ The report also deals with the increasing presence of non-agricultural buyers in the market of agricultural lands, which causes an increase in the price of agricultural lands. ${ }^{60}$ The British report draws the attention to the importance of registers concerning cross-border acquisitions: "...the present system of land registration was established by the Land Registry Act 1875. However registration was not compulsory initially. Compulsory land registration began in London in 1899, but did not extend to all rural areas until 1990. This does not affect land which has not changed hands and the Land Registry estimates that $20 \%$ of the land mass in England and Wales remains unregistered and most of

\footnotetext{
${ }^{56}$ Hannes Kronaus, National report - Austria, 6-9. (hereinafter referred to as Austrian report), the report is to be found at http://www.cedr.org/congresses/potsdam/potsdamcom2.php

${ }^{57}$ About the British land law in details, see Donald Rennie, Land ownership and land use in the United Kingdom, in: Current challenges of the European legislation on agricultural land (ed.: Csilla Csák), Novotni, Miskolc, 2010, 255-262; Donald Rennie, Some aspects of agricultural law in Scotland, JAEL, 6/2008, 26-48.

${ }^{58}$ Ludivine Petetin, Michael Taylor, National report - the United Kingdom, 2. (hereinafter referred to as British report), the report is to be found at http://www.cedr.org/congresses/potsdam/ potsdamcom2.php. About the Scottish intention in details, see British report, 15-16.

${ }^{59}$ British report, 13.

${ }^{60}$ British report, 13. There is similar conclusion in Philip Day, The family farm and it's succession within the family, in: Agricultura Familiar (ed.: Leticia Bourges, Esther Muniz Espada), Ministerio de Agricultura, Madrid, 2014, 178.
} 
this is rural land. This means that it is very difficult to produce accurate statistics on the identity of land owners and the nature of land holding in the UK... Recently in a speech in Singapore Prime Minister David Cameron has called for more transparency in land ownership in an effort to overcome fears that proceeds of foreign crime are being "laundered" through the UK property market. He has announced proposals for the Land Registry to publish details of land held by foreign investment companies. The Financial Times has estimated that at least $£ 122$ billion of property in England and Wales is owned by offshore companies. Most of this investment will be in commercial and residential property in London and the south east, but some will be in agricultural property across the UK." 61

\section{CONCLUSION}

The regulation concerning the acquisition of agricultural and forestry lands is a topical and essential (political) issue in numerous countries of Europe and all around the world. Taking the state sovereignty, food security, land-hunger and soil erosion into consideration, the importance of agricultural and forestry lands in the regime of independent and sovereign states is strategic and unquestionable. That is the reason why almost all EU MSs have some kind of a regulation concerning agricultural and forestry lands. Even in the Old Member States of the EU (Austria, Germany, UK), the decision-makers face the challenges of globalization and shall decide what serves better the interest of their voters. For that very reason, it is essential to end of the infringement procedures against some of the New Member States initiated by the European Commission in connection with the acquisition of the ownership of agricultural lands.

${ }^{61}$ British report, 14. 
Др Јанощи Е. Силађи, ванредни иррофесор

Универзииеети у Мищколиу

Правни факулимети

civdrede@uni-miskolc.hu

\section{Стицање права својине на пољопривредном земљишту у Мађарској, с посебним освртом на право Европске уније и права других земаља}

Сажеетиак: У раду се анализирају йравна йийања у вези са йравом својине (и у одређеној мери иравом уйойребе) на иольоиривредном и щумском

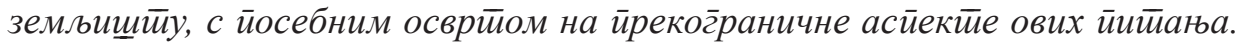
Ауйор йолази од иррейиостивке да су она у свакој држави акииуелна. У раду

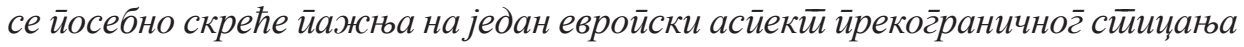
ирава својине на йољоиривредном земљищйу, йj. на нова ирравила усвојена у земљама чланицама које су Евройској унији ирисииуииле 2004, односно 2007. године. Током 2014. и 2015. године Комисија Евройске уније је анализирала ирравно уређење стиицање иррава својине на йољойривредном земљищйу у новим чланицама Уније и иррема већини њих (Буг̄арској, Мађарској, Лейонији, Литиванији и Словачкој) иокренула ирред Евроиским судом ирравде иоосииуике због йовреде обавеза иррема Заједници. Осим ирава ових држава, у раду се анализира йравно уређење овог йитиања и у ситаријим државама чланицама, као и у неким државама које нису чланице Уније. У раду се йридаје значај и

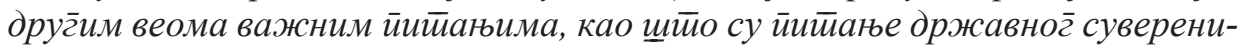
$\bar{и} е \bar{и} а$, иохлеие за йољоиривредним земљищиеем, ерозије йла, која сва могуу да буду од уйицаја на ирравно уређивање стициаға йрава својине на йољойривредном земьищйу у йојединим земьама.

Кључне речи: земљищно ираво - иољьоиривредно земљищие -сииицање ирава својине

Датум пријема рада: 27.10.2016. 